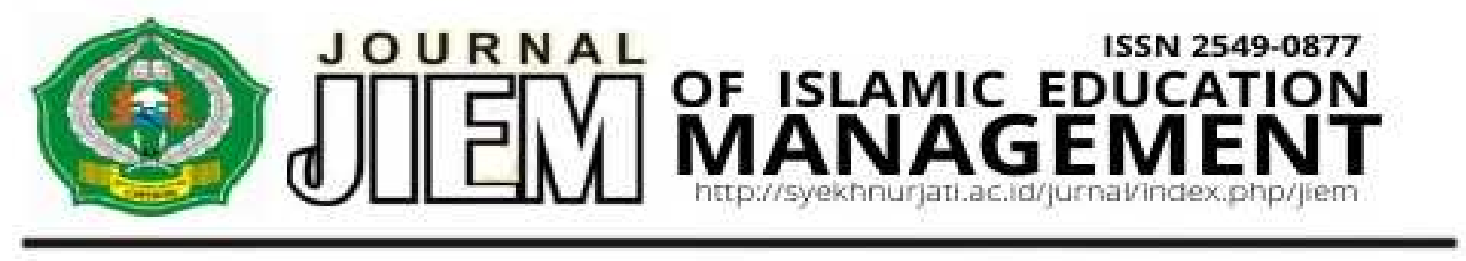

\title{
ANALISIS GAYA KEPEMIMPINAN KOORDINATOR WILAYAH BIDANG PENDIDIKAN DALAM MEMBERDAYAKAN TENAGA HONORER DI KOORDINATOR WILAYAH BIDANG PENDIDIKAN KECAMATAN KEDAWUNG KABUPATEN CIREBON
}

\author{
Koko Santoso, Maman Supriatman, Suhatma \\ Institut Agama Islam Negeri (IAIN) Syekh Nurjati Cirebon \\ Email: kokosantoso_std@syekhnurjati.ac.id, mamansupriatman@syekhnurjati.ac.id, \\ suhatma@syekhnurjati.ac.id
}

\begin{abstract}
ABSTRAK
Gaya kepemimpinan merupakan suatu aspek yang sangat penting dalam pengelolaan lembaga pendidikan guna mencapai tujuan instansi pendidikan. Pemberdayaan tenaga honorer dapat dilihat dari cara pemimpin dalam memimpin instansinya. Fakta di lapangan terdapat harmonisasi internal kantor serta minimnya kesenjangan antara staf PNS dan staf honorer. Penelitian dilakukan untuk mengetahui sejauh mana gaya kepemimpinan koordinator wilayah bidang pendidikan dalam memberdayakan tenaga honorer di koordinator wilayah bidang pendidikan kecamatan kedawung kabupaten Cirebon. Metode yang digunakan kualitatif deskriptif empiris. Pengambilan data melalui wawancara mendalam, observasi mendalam, dan dokumentasi. Teknik analisis data menggunakan kualitatif deskriptif yang meliputi reduksi data, penyajian data, dan verifikasi data. Hasil penelitian menunjukkan bahwa 1) gaya kepemimpinan yang diterapkan di koordinator wilayah bidang pendidikan kecamatan Kedawung didominasi oleh gaya kepemimpinan transformatif, 2) upaya-upaya yang dilakukan oleh koordinator wilayah bidang pendidikan kecamatan Kedawung yaitu membenahi kantor agar lebih nyaman bagi karyawan, sering mengadakan syukuran makan-makan, menciptakan lingkungan organisasi yang menyenangkan yaitu dengan menghindari cara-cara repsesif dalam memimpin. 3) gaya kepemimpinan mempengaruhi optimal atau tidaknya kinerja tenaga honorer.
\end{abstract}

Kata Kunci : Gaya Kepemimpinan, Optimalisasi, Pegawai Honorer

\begin{abstract}
Leadership style was a very important aspect in the management of educational institutions in order to achieve the goals of educational institutions. Empowerment of honorary staff can be seen from the way leaders lead their institutions. The facts in the field are there was internal office harmonization and the minimum gap between civil servant staff and
\end{abstract}


honorary staff. The study was conducted to determine the extent of the leadership style of the regional education coordinator in empowering the honorary staff in the regional education coordinator of the Kedawung sub-district, Cirebon district. The method used was qualitative descriptive empirical. Retrieval of data through in-depth interviews, in-depth observation, and documentation. The data analysis technique uses descriptive qualitative which includes data reduction, data presentation, and data verification. The results showed that 1) the leadership style applied in the education area coordinator of the Kedawung subdistrict was dominated by the transformative leadership style, 2) the efforts made by the regional coordinator for education in the Kedawung sub-district, namely fixing the office so that it was more comfortable for employees, often holding meals and thanksgiving, creating a pleasant organizational environment, namely by avoiding repessive ways of leading. 3) leadership style influences the optimal performance of honorary staff.

Keywords: Leadership Style, Optimization, Employees Honorary

\section{PENDAHULUAN}

Pemimpin adalah individu yang melakukan proses mempengaruhi sebuah kelompok atau organisasi untuk mencapai suatu tujuan yang telah disepakati bersama. Sedangkan kepemimpinan adalah gaya yang dipilih seseorang dalam memanage organisasi atau kelompoknya. Kepemimpinan merupakan ciri seorang pemimpin dalam mengambil suatu keputusan. Karena organisasi tentunya memiliki tujuan yang hendak dicapai (kartono, 2000). Gaya yang dipilih biasanya menyesuaikan jenis dan tujuan organisasinya. Terkait dengan kepemimpinan memang sudah menjadi suatu hal yang sangat menarik untuk dikaji para peneliti guna memperbanyak perbendaharaan cara yang dipakai dalam memimpin suatu organisasi.

Teori kepemimpinan telah berkembang sejak puluhan tahun yang lalu dan sudah banyak berbagai referensi dalam bentuk beraneka macam mengenai table ini yang dihasilkan dari berbagai penelitian. Fungsi kepemimpinan dalam sebuah organisasi atau kelompok sangat penting karena fungsi kepemimpinanlah sebuah organisasi dapat mencapai tujuannya melalui jalan dan cara yang benar. Memahami dengan baik dan berinteraksi dengan orang lain dalam mempengaruhi orang untuk melakukan sesuatu. Gaya tersebut bisa berbeda-beda atas dasar motivasi, kuasa, ataupun orientasi terhadap tugas atau orang tertentu. Diantara beberapa gaya kepemimpinan, terdapat pemimpin yang positif dan negatif, dimana perbedaan itu didasarkan pada cara dan upaya mereka memotivasi bawahannya. Jika pendekatan dalam pemberian motivasinya ditekankan pada reward, berarti gaya kepemimpinan tersebut dikatakan positif. Sebaliknya, jika pendekatan dalam pemberian motivasinya ditekankan pada punishment, maka gaya kepemimpinan tersebut dikatakan negatif.

Berbicara mengenai kepemimpinan memang sangat luas sekali, bisa terjadi pada diri sendiri maupun kepemimpinan yang sekupnya lebih luas lagi seperti korwil pendidikan. Koordinator wilayah kecamatan bidang pendidikan adalah pejabat fungsional atau pegawai aparatur sipil negara yang bertugas melakukan koordinasi layanan administrasi pada satuan pendidikan di wilayah kecamatan. Orientasi pengadministrasiannya tidak hanya pada lembaga pendidikan formal seperti taman 
mengenai konsep kepemimpinan sangat membantu seseorang dan organisasi bekerja lebih efektif dan efisien dalam mencapai tujuan dan kondisi yang diinginkan.

Gaya kepemimpinan adalah cara seseorang dalam bersikap, berkomunikasi,

Berdasarkan hasil observasi awal, peneliti tidak menemukan arsip administrasi mengenai sejarah Korwil Pendidikan Kedawung. Akan tetapi peneliti mewawancarai salah seorang pengawas Sekolah Dasar (SD) yang ada di tempat ini yaitu Dwinita Listyawati. Berdasarkan penuturannya, korwil bidang pendidikan kecamatan Kedawung ini dulunya adalah UPT Pendidikan. Akan tetapi tidak ada yang tahu sejak kapan berdirinya karena tidak ada bukti administrasi secara tertulis. Pada bulan Oktober 2018 UPT Pendidikan Kedawung ini berubah menjadi korwil bidang Pendidikan kecamatan Kedawung. Harusnya, korwil ini di bawah naungan kecamatan. Namun, kurang lebih setahun berjalan, alih-alih pelaporan bulanan itu ke kecamatan malah ke pemerintah daerah sebagaimana saat namanya masih UPT Pendidikan.

Sementara itu menurut Siti Ukari selaku kepala UPT Pendidikan Kecamatan Kedawung tahun 2013, melalui penilik lembaga kursus Taufik Hidayat mengungkapkan Pemkab Cirebon perlu peninjauan ulang pembubaran UPTD karena pendidikan di Kabupaten Cirebon belum siap. Menurut Taufik, Pemkab Cirebon perlu melakukan kajian terlebih dahulu pada satuan tingkat pendidikan seperti SD dengan jumlah siswa di bawah 400 orang. Sebelumnya, Sekretaris Daerah Kabupaten Cirebon, Yayat Ruhyat, mengatakan pembubaran UPTD Pendidikan merupakan kebijakan pemerintah pusat yang tertuang dalam peraturan Kementerian Dalam Negeri (kemendagri). kanak-kanak (TK) atau sekolah dasar (SD) saja, akan tetapi berlaku juga pada lembaga pendidikan nonformal bahkan informal seperti kelompok belajar (kober), lembaga kursus pendidikan (LKP), maupun pendidikan kesetaraan dan keaksaraan.

memiliki perbedaan yang mendasar. Perbedaan antara tenaga honorer dan PNS dapat terlihat dalam peraturan perundangundangan secara implisit. Tenaga honorer diangkat untuk melaksanakan tugas tertentu, sedangkan PNS diangkat untuk menduduki jabatan pemerintahan. Perbedaan inilah yang menjadi kesenjangan dan honorer memiliki harapan besar untuk menjadi PNS.

Dalam ruang lingkup korwil pendidikan Kecamatan Kedawung, kesenjangan tersebut dianggap penting. Oleh karenanya, penerapan gaya kepemimpinan korwil bidang pendidikan ini kiranya mampu mengatasi kesenjangan antara PNS dan juga tenaga honorer. Kepemimpinan yang handal sangat diperlukan guna memotivasi khususnya tenaga honorer supaya tujuan organisasi dapat tercapai secara optimal. Korwil Pendidikan Kedawung baru berjalan sekitar 1 tahun sebab dulunya adalah UPT Pendidikan Kedawung. Secara struktural tidak banyak terjadi perubahan, hanya ketuanya saja yang berubah. Ketika masih menjadi UPT diketuai oleh Siti Ukari, pasca perubahan menjadi korwil pendidikan ia digantikan oleh Purwati Sariwulan. Hasil pengamatan sementara di korwil bidang pendidikan kecamatan Kedawung ini dihadapkan pada permasalahan yaitu pengalaman pertama menjadi korwil bidang pendidikan Kecamatan Kedawung.

Kurang berpengalamannya dalam pengelolaan korwil pendidikan ditambah terdapat 3 staf tenaga honorer baru yang tidak memegang data-data atau arsip pada saat masih menjadi UPTD membuat peneliti tertarik untuk meneliti tempat ini. 
Dalam praktiknya, yang bekerja pada tataran korwil pendidikan kedawung ini tidak hanya terdiri dari para PNS saja, akan tetapi juga terdapat tiga pegawai honorer. Meskipun pegawai negeri sipil maupun tenaga honorer sama-sama melaksanakan tenaga honorer sama-sama melaksanakan tugas dalam instansi pemerintah, namun penulis akan melakukan penelitian dengan judul "Analisis Gaya Kepemimpinan Koordinator Wilayah Bidang Pendidikan dalam Memberdayakan Tenaga Honorer di Koordinator Wilayah bidang Pendidikan Kecamatan Kedawung Kabupaten Cirebon".

\section{METODE}

Penelitian ini menggunakan pendekatan kualitatif deskriptif empiris, Penelitian kualitatif merupakan suatu aktivitas yang bersituasi yang menempatkan pengamat di dunia. Ia terdiri atas seperangkat praktik interpretif dan material yang menyebabkan dunia menjadi tampak/terlihat (Creswell, 2007). Praktik-praktik ini mentransformasi dunia. Mereka mengubah dunia menjadi serangkaian representasi, termasuk catatan lapangan, interview, percakapan, foto, rekaman, dan memo diri. Pada level ini, penelitian kualitatif meliputi suatu pendekatan interpretif dan naturalistik kepada dunia. Di samping mempertahankan pendekatan penelitian kualitatif yang tradisional seperti pendekatan interpretif naturalistik dan makna, definisi ini juga mengemukakan suatu orientasi yang cukup kuat ke arah dampak penelitian kulitatif dan dalam mentransformasi dunia.

Penelitian ini dimulai saat tahap persiapan hingga tahap penyelesaian. Informan dalam penelitaian ini terdiri atas: korwil bidang pendidikan, pengawas SD, staf tata kelola, dan staf tata laksana di korwil bidang pendidikan kecamatan Kedawung. Dalam pengumpulan data, peneliti menggunakan 3 teknik: pertama,
Berangkat dari permasalahan yang sudah dijelaskan di atas, penulis sangat tertarik untuk menganalisis lebih dalam mengenai gaya kepemimpinan dan optimalisasi etos kerja para tenaga honorer. Dengan mengetahui fenomena-fenomena yang terjadi di lapangan tentang gaya kepemimpinan korwil pendidikan, maka responden atau orang yang diwawancarai, dengan atau tanpa menggunakan pedoman (guide) wawancara dimana pewawancara dan informan terlibat dalam kehidupan sosial yang relatif lama (Sutopo, 2006). Ketiga, dokumentasi yang dilakukan peneliti yaitu dengan mengambil gambar dan rekaman dari berbagai kegiatan yang dilakukan oleh korwil. Teknik analisis data yang dilakukan oleh peneliti yaitu menggunakan teknik analisis kualitatif deskriptif meliputi pengumpulan data, reduksi data, penyajian data, dan penarikan kesimpulan.

\section{HASIL DAN PEMBAHASAN}

Dari hasil pengambilan data yang telah dilakukan oleh peneliti di lapangan dapat dijelaskan beberapa informasi terkait gaya kepemimpinan korwil bidang pendidikan dalam memberdayakan tenaga honorer di korwil bidang pendidikan kecamatan Kedawung. Secara garis besar, beberapa poin yang dibahas dalam penelitian ini yaitu mengenai gaya kepemimpinan, upaya-upaya yang dilakukan korwil dalam memberdayakan tenaga honorer serta pengarh gaya kepemimpinan terhadap optimalisasi kinerja pegawai honorer.

Banyak sekali cara yang dipakai oleh seorang pemimpin dalam memimpin bawahannya. Salah satu indikasi pemakaian gaya kepemimpinan bisa dilihat dari cara seorang pemimpin dalam menggerakkan bawahannya. Kaitannya dengan menggerakkan, Kadmi biasanya memberikan suri tauladan, memberi contoh yang baik kepada bawahan supaya mereka 
observasi mendalam dengan melakukan pengamatan langsung ke tempat penelitian dalam tempo waktu yang cukup lama hingga memperoleh kejenuhan data. Kedua, wawancara mendalam yaitu proses memperoleh keterangan untuk tujuan penelitian dengan cara tanya jawab sambil bertatap muka antara pewawancara dengan, Kedawung ada pegawai struktural seperti staf yang mengurusi keuangan, kepegawaian dan ada yang mengurusi bagian administrasi. Selanjutnya ada pegawai fungsional seperti pengawas SD (sekolah dasar), pengawas TK (taman kanak-kanak), penilik Kober (kelompok bermain), penilik kesetaraan dan keaksaraan, dan penilik LKP (lembaga kursus pendidikan). Selain itu ada lagi bagian jaskeb (jasa kebersihan) dan penjaga malam.

Kepemimpinan yang dilakukan tidak lepas dari sifat pemimpin itu sendiri. Seperti halnya pemberian peringatan mulai dari cara-cara yang halus dan sopan maupun cara-cara yang tidak mengenakan. Dalam hal ini korwil bidang pendidikan lebih memilih cara-cara step by step serta halus dan sopan sebab lebih mengutamakan etika. Penggunaan cara step by step yang dilakukan oleh Kadmi tersebut menunjukkan bahwa korwil bidang pendidikan kecamatan Kedawung bukan korwil yang bersifat arogan. Ia lebih menggunakan cara yang etis seperti menegur dalam kondisi empat mata di ruangannya.

Hal tersebut ia lakukan karena ia anggap di korwil tersebut seperti keluarganya semua. Maka dari itu faktor kekeluargaan lebih diutamakan demi terjaganya keharmonisan suasana kantor. Hal tersebut didukung oleh pernyataan Kusmayadi selaku staf honorer yang menyetakan bahwa korwil mengupayakan penciptaan lingkungan kantor yang nharmonis. Segala sesuatu dilakukan secara mematuhi peraturan. Jadi, dalam hal menggerakkan bawahan yang berorientasi pada suri tauladan tersebut Kadmi menggunakan gaya kepemimpinan transformatif. Berkaitan dengan pengorganisasian perencanaan yang sudah dibuat, Kadmi membagi tugas antar staf. Di korwil bidang pendidikan kecamatan

pendidikan Kedawung dimana terdapat seorang guru yang melakukan pelanggaran PP No 53 Tahun 2010. Kasus yang mana sudah ada terlebih dahulu sebelum Kadmi dipindah tugaskan di korwil bidang pendidikan Kecamatan Kedawung tersebut masih terus diusut. Dinas pendidikan pun menghendaki demikian. Meskipun pelanggaran sudah jelas, korwil masih menghendaki BAP dan pemberian kesempatan lagi. Pendekatan kekeluargaan masih dipilih sebab korwil percaya bahwa setiap orang pasti bisa berubah kearah yang lebih baik.

Berkaitan dengan pemberian sanksi, korwil bidang pendidikan kecamatan Kedawung hanya melakukan prosedural peringatan empat mata dan BAP saja, sementara untuk kebijakan pemberian sanksi diserahkan kepada pemerintah terkait. Konsekuensi atas ketidakdisiplinan yang terjadi di korwil bidang pendidikan kecamatan Kedawung adalah teguran. Unsur keharmonisan kantor sangat dijaga demi tercapainya misi yang berorientasi pada pelayanan yang baik. Untuk mendisiplinkan pegawai, Kadmi tidak menghendaki adanya ancaman-ancaman, ia memilih cara-cara seperti memberikan contoh suri tauladan kepada yang lainnya. Dalam hal mencegah perlakuan kesalahan yang sama, Kadmi senantiasa saling mengingatkan. Hal tersebut biasa dilakukan dengan cara-cara yang sopan seperti teguran. Teguran yang dilakukan menggunakan bahasa yang sopan dan cara yang baik seperti menegur bukan di tempat 
kekeluargaan yang membuat lingkungan kantor merasa nyaman dan terdapat peningkatan kinerja yang lebih baik.

Berkaitan dengan upaya-upaya yang dilakukan korwil dalam memberdayakan kinerja bawahannya dapat diamati ketika korwil memiliki masalah. Terdapat contoh kasus nyata yang terjadi di korwil bidang

Gaya kepemimpinan merupakan cara yang dipakai oleh seorang pemimpin dalam mempengaruhi bawahannya. Optimal atau tidaknya kinerja bawahan dipengaruhi oleh kepemimpinan seorang pemimpin. Dalam hal penyelarasan visi dan misi korwil, Kadmi memilih dengan menggunakan cara kekeluargaan. Ia menganggap bahwa cara tersebut bisa membuat internal kantor menjadi harmonis. Dengan keharmonisan tersebut, para pegawai akan betah dan bekerja pun lebih optimal. Penyelarasan cara yang dilakukan Kadmi dalam mewujudkan visi dan misi korwil tersebut dengan cara menumbuhkan rasa kekeluargaan nampaknya dirasa cocok untuk diterapkan. Pemilihan tersebut mempengaruhi kinerja pegawai di dalam lingkungan kantor. Kondisi yang harmonis akan meningkatkan kedisiplinan kinerja staf dan pegawai lainnya. Hal tersebut didukung oleh pernyataan Kusmayadi selaku staf honorer yang menyatakan bahwa penciptaan lingkungan pendukung kantor tidak lepas dari kepemimpinan ketuanya.

Berdasarkan visi dan misi korwil bidang pendidikan kecamatan Kedawung yang lebih mengutamakan pada pelayanan, Kusmayadi berpendapat bahwa korwil tidak membeda-bedakan pelayanan untuk penilik, pengawas, maupun orang-orang yang membutuhkan khususnya bagian administrasi kantor.

Banyak cara yang biasa dilakukan umum melainkan dengan cara di panggil ke ruangannya.

Di korwil bidang pendidikan kecamatan Kedawung sendiri keteladanan sangat dijunjung tinggi. Kadmi menuturkan bahwa upaya keteladanan itu tidak hanya dilakukan di dalam kantor, akan tetapi di luar kantor pun demikian.

bahwa dengan memberikan respon yang baik kepada bawahan ketika sedang dibutuhkan akan meningkatkan motivasi bawahannya.

Tindakan lain yang biasa dilakukan korwil ialah dengan cara mengadakan syukuran kecil-kecilan ketika momenmomen tertentu. Momen di sini biasanya momen hari perayaan ulang tahun, syukuran anak, ataupun momen setelah gajian. Biasanya di korwil bidang pendidikan kecamatan Kedawung mengadakan acara makan-makan kecil di lingkungan kantor. Cara-cara tersebut diyakini bisa menstimulasi bawahan hingga bersemangat dalam bekerja.

Tentunya di samping cara-cara tersebut, masih terdapat keinginan khususnya keinginan staf tenaga honorer yang menginginkan pengangkatan menjadi PNS. Hal tersebut ditanggapi oleh Kadmi yang mengupayakan realisasi hal tersebut. Ia menyadari bahwa menjadi tenaga honorer itu tidak mudah, dibalik pekerjaan sehari-harinya di lingkungan kantor terdapat segudang kebutuhan yang harus dipenuhi. Dedikasi staf tenaga honorer yang sudah bekerja di korwil bidang pendidikan kecamatan Kedawung sejak tahun 2005 menjadikan korwil mengamini keinginan staf administrasi honorer. Selain itu, cara yang biasa dilakukan dalam menyelasaikan tugas yang baru dan sulit dimengerti biasanya dilakukan dengan ngobrol santai ketika waktu senggang.

Pemimpin menstimulsi pengikutnya 
seorang pemimpin dalam memberikan motivasi kepada bawahannya. Ada yang melalui kata-kata, da nada juga yang melakukannya dengan tindakan. Korwil bidang pendidikan kecamatan Kedawung melakukannya dengan cara tindakan perlakuan responsif. Kadmi beranggapan

Pada tataran ini pola perilaku seorang pemimpin harus menjadi suri tauladan bagi para komponen organisasi pendidikan, tutur katanya harus sesuai dengan perbuatannya, atau tidak munafik. Pemimpin seperti ini biasanya akan dikagumi, dihormati dan dipercayai oleh para bawahannya. Di korwil bidang pendidikan kecamatan Kedawung sendiri terdapat dua orang staf administrasi honorer yang mana sangat disayangkan oleh korwil karena masih belum diangkat menjadi PNS. Bentuk perhatian yang dilakukan Kadmi yaitu dengan cara syukuran dan juga pemberian pujian kepada bawahan yang menjalankan tugas dengan baik. Hal ini dilakukan guna meningkatkan kepercayaan diri bawahan dan juga meningkatkan kekeluargaan internal kantor.

Dalam hal pendampingan, tidak hanya dilakukan oleh korwil akan tetapi pegawai lain pun memback upnya. Seperti pak Wanto selaku petugas piket yang merupakan orang yang paling lama dibandingkan pegawai lainnya di korwil bidang pendidikan kecamatan Kedawung. Hal tersebut dibenarkan oleh kusmayadi selaku staf administrasi korwil bidang pendidikan kecamatan Kedawung. Dimana pendampingan dilakukan sejak ia masih magang hingga sekarang bekerja sebagai staf administrasi. Pendampingan disini lebih kepada cara-cara pengaplikasian komputer yang berkaitan dengan administrasi perkantoran. untuk memikirkan kembali cara atau metode kerja yang lama dan menilai kembali nilai-nilai dan kepercayaan mereka yang lama. Dimensi ini berkenaan dengan derajat dimana para pengikutnya disediakan tugas-tugas yang menentang dan didorong untuk memecahkan masalah dengan cara mereka sendiri.

Ada sehingga diketahui makna yang terkandung di dalamnya.

Pandangan pemimpin gaya kepemimpinan partisipatif dalam hal sifat pemimpin yaitu apabila dalam kepemimpinannya dilakukan secara persuasive, menciptakan kerja sama yang serasi, menumbuhkan loyalitas dan partisipatif para bawahannya. Untuk gaya kepemimpinan transaksional dalam hal sifat pemimpin, yaitu apabila dalam kepemimpinannya melibatkan nilai-nilai yang relevan dengan proses pertukaran seperti kejujuran, tanggung jawab, dan timbal balik.sedangkan gaya kepemimpinan transformatif dalam hal sifat pemimpin yaitu ketika dalam kepemimpinannya didasarkan pada kepercayaan dan komitmen (Robbins \& Coulter, 2002).

Korwil sebagai pemimpin instansi selalu melakukan komunikasi dengan para bawahan khususnya dengan para staf tata laksana. Komunikasi biasa dilakukan pada saat jam kerja maupun di luar jam kerja. Hal itu ia lakukan agar dapat mengakrabkan hubungannya dengan para bawahan. Tak jarang pula korwil ataupun para pengawas di korwil bidang pendidikan Kecamatan Kedawung mengadakan acara makanmakan syukuran. Biasanya syukuran dilakukan ketika awal bulan setelah turun gaji atau pada saat moment perayaan tertentu. Dengan diadakannya syukuran di sini, semua pegawai menjadi lebih akrab sebab internal kantor tidak hanya diisi dengan kesibukan tupoksi pekerjaan 
Setelah dilakukan pengklasifikasian dan pemaparan data temuan lapangan yang dilakukan dengan menggunakan metode pengumpulan data wawancara mendalam, observasi mendalam, dan dokumentasi. Selanjutnya data hasil temuan lapangan akan dianalisis dan dikaji dengan teori yang

usaha-usaha harmonisasi internal kantor membuat para bawahan merasa bahwa lingkungan kantor sudah seperti lingkungan keluarga. Usaha-usaha tersebut membuat para staf tata laksana menjadi betah dan berkomitmen untuk loyal dan disiplin kerja. Hal itu diperkuat oleh bukti dari hasil observasi yang dilakukan peneliti pada saat magang hingga melakukan penelitian secara resmi, staf tata laksana begitu disiplin dalam hal jam kerja serta melakukan pelayanan yang ramah sesuai dengan visi misi korwil bidang pendidikan Kecamatan Kedawung.

Dari beberapa hal yang dilakukan korwil akan membuat hubungan antara korwil dan pegawai lainnya atau dalam hal ini staf tata laksana menjadi percaya dan berkomitmen. Hal itu akan membuat kerjasama yang lebih bersemangat dan akan timbul loyalitas dari para bawahan. Jadi dalam hal pandangan korwil di koordinator wilayah bidang pendidikan Kecamatan Kedawung lebih cenderung menerapkan gaya kepemimpinan transformatif.

Pandangan

pemimpin

gaya

kepemimpinan partisipatif dalam hal pengambilan keputusan dan kebijakan, kepemimpinan ini berkonsultasi dengan bawahan dan menggunakan saran mereka sebelum mengambil suatu keputusan. Untuk gaya kepemimpinan transaksional dalam hal pengambilan keputusan dan kebijakan, pemimpin mendasarkan pada tupoksi yang sudah ditetapkan pada saat awal saja. Namun berbeda dengan kepemimpinan masing-masing saja, akan tetapi dihiasi dengan seringnya perayaan syukuran makan-makan. Dengan hal-hal tersebut, para pegawai khususnya staf tata laksana yang notabene masih menghonor menjadi lebih bersemangat.

Cara yang dilakukan Kadmi selaku korwil kaitannya dengan komunikasi dan

Kadmi mengatakan bahwa pengambilan keputusan dari setiap masalah yang terjadi di koordinator wilayah bidang pendidikan Kecamatan Kedawung sebagai pemimpin selalu meminta ide, saran, atau pendapat dari para pegawai lain untuk dijadikan bahan pertimbangan. Namun keputusan akhir tetap berada di tangan korwil dengan mengutamakan azas kekeluargaan. Jadi dalam hal pengambilan keputusan maka gaya kepemimpinan yang diterapkan oleh Kadmi selaku korwil bidang pendidikan Kecamatan Kedawung cenderung memakai gaya kepemimpinan partisipatif sekaligus gaya kepemimpinan transformatif.

Dikatakan gaya kepemimpinan partisipatif karena korwil selalu meminta saran, ide, atau pendapat dari bawahan. Sekaligus dikatakan dalam hal ini memakai gaya kepemimpinan transformatif karena selalu menghendaki pengampunan sebab korwil beranggapan bahwa setiap manusia pasti akan menyadari kesalahannya dan berubah menjadi lebih baik lagi. Hal itu terbukti ketika terdapat kasus guru yang sudah lama tidak mengajar, korwil berdiskusi dengan para bawahan dan berkordinasi dengan dinas terkait guna menyikapi permasalahan tersebut. Akan tetapi dengan adanya masukan-masukan dari para bawahan dan instruksi dari dinas, korwil masih menghendaki adanya pengampunan dan sebisa mungkin meminimalisir sanksi yang akan diberikan kepada guru tersebut. 
transaksional, kepemimpinan transformatif dalam hal pengambilan keputusan menghendaki adanya inovasi demi tercapainya tujuan instansi seefektif dan seefisien mungkin (Robbins \& Coulter, 2002).

Dengan disiplin, instansi akan terus berkembang. Korwil menghendaki adanya perubahan-perubahan cara yang dipakai dalam setiap pekerjaan guna kemajuan instansi pendidikan. Korwil juga mengingatkan supaya jangan sampai ada kesalahan-kesalahan mendasar yang terulang kembali. Pengarahan tidak hanya sekadar pemberian peringatan, akan tetapi pembangunan internal kantor yang lebih harmonis mampu membuat para pegawai menjadi lebih disiplin dan seakan enggan melakukan hal-hal negatif di luar kewajiban yang menciderai kepercayaan Kadmi selaku korwil bidang pendidikan Kecamatan Kedawung.

Berdasarkan pengarahan yang dilakukan Kadmi yang berorientasi pada harmonisasi internal, menghendaki adanya inovasi, serta visi misi yang mengutamakan pada pelayanan, dapat disimpulkan bahwa dalam hal pemberian motivasi, Kadmi menerapkan gaya kepemimpinan transformatif.

Banyak faktor yang mempengaruhi tinggi rendahnya kinerja pegawai, salah satunya adalah kepemimpinan. Banyak gaya yang digunakan pemimpin dalam mempengaruhi bawahan seperti yang dilakukan oleh Kadmi dalam memimpin korwil bidang pendidikan kecamatan Kedawung yang memiliki kecenderungan pemakaian gaya kepemimpinan
Mengenai pengarahan bawahan, korwil selalu meminta kepada semua pegawai supaya disiplin dalam segala hal seperti menaati peraturan-peraturan yang telah ditetapkan korwil, disiplin jam kerja, dan pemberian pelayanan yang baik sesuai dengan visi dan misi korwil bidang pendidikan Kecamatan Kedawung yang berorientasi pada pelayanan.

Berikut ini akan dirinci mengenai upayaupaya yang dilakukan oleh korwil bidang pendidikan kecamatan Kedawung berdasarkan indikator-indikator gaya kepemimpinan transformatif:

Karisma

Kadmi selaku korwil bidang pendidikan kecamatan Kedawung mengutamakan keteladanan. Ia berpendapat bahwa segala sesuatu itu berawal dari diri sendiri. Ketika pribadi baik, lingkungan akan mengikuti baik.

Motivasi Inspiratif

Banyak cara yang dilakukan dalam memberikan motivasi, ada yang melalui kata-kata ada juga yang melalui dengan cara tindakan. Cara yang dipilih Kadmi dalam memberikan motivasi yaitu dengan tindakan. Dengan memberikan perilaku baik dan responsif ketika sedang dibutuhkan akan mengoptimalkan kinerja staf.

Stimulus Intelektual

Kadmi tidak melakukan penekanan kepada para staf dalam menjalankan tugasnya, akan tetapi ia menyediakan waktu untuk berdiskusi terkait pekerjaan-pekerjaan staf. Sedangkan untuk penyelesaian masalahnya, staf memikirkan sendiri cara seperti apa yang ia pilih sebagai solusi menyelesaikan pekerjaannya.

Perhatian Individual

Dalam hal perlakuan terhadap individuindividunya atau dalam hal ini staf honorer, Kadmi menginisiasi syukuran berupa 
transformatif. Dengan kepemimpinan transformatif, para pengikut merasakan kepercayaan, kekaguman, kesetiaan, dan penghormatan terhadap pemimpin sehingga mereka termotivasi untuk melakukan lebih daripada yang awalnya diharapkan oleh mereka.

Berdasarkan hasil observasi, dokumentasi, dan wawancara dengan para informan pada penelitian ini, terdapat pengaruh gaya kepemimpinan terhadap optimalisasi kinerja tenaga honorer. Pemimpin korwil bidang pendidikan kecamatan Kedawung sebelumnya adalah Harbino dimana pada saat itu nama instansinya masih Unit Pelaksana Teknis Daerah (UPTD). Pada saat itu kondisi instansi secara administrasi belum bisa dikatakan baik. File-file masih tertumpuk menjadi satu, baik soft file maupun hard file. Hal ini disinyalir karena tidak adanya kejelasan dan ketegasan mengenai proses pengadministrasian.

Di samping itu instansi masih belum memiliki kejelasan visi misi secara lisan maupun tertulis. Budaya dan nilai-nilai instansi belum jelas dan benar-benar diterapkan. Gaya kepemimpinan yang diterapkan oleh Harbino adalah gaya kepemimpinan otokratis, yang mana terdapat kecenderungan tendensi yang lebih diktator kepada pegawai. Contohnya Harbino lebih ke arah memberikan perintah apa saja kepada pegawai honorer, ketika Harbino berkata A maka pegawai juga harus melakukan A. Pegawai hanya melakukan perintah, tidak ada kesadaran dari dirinya sendiri untuk bekerja lebih dari standar yang ditetapkan. makan-makan di lingkungan kantor dan selalu memberikan pujian atas pekerjaanpekerjaan yang telah diselesaikan. Hal tersebut ia yakini akan meningkatkan kepercayaan diri bawahan dan juga meningkatkan kekeluargaan internal kantor.

galon, tidak ada pegawai yang berani berkata kepada atasan mereka karena adanya rasa sungkan. Hubungan kedekatan Harbino dengan pegawai terjalin formal atasan dengan bawahan.

Ketika peralihan kepemimpinan pada Purwatisariwulan, satu persatu internal instansi mulai dibenahi dengan melakukan perubahan-perubahan. Perubahan yang pertama dilakukan adalah membangun visi misi secara lisan dan tertulis. Dalam hal ini peneliti tidak menemukan visi misi pada kepemimpinan Purwatisariwulan. Berdasarkan penuturan dari Wahyu Singgih selaku staf honorer pada saat peneliti melaksanakan PLP, terdapat perubahan orientasi budaya kantor. Dari yang semula kaku dan cenderung bersuasana tegang, menjadi lebih santai dengan adanya budaya makan-makan di lingkungan kantor.

Tidak lama menjabat di korwil bidang pendidikan kecamatan Kedawung, Purwatisariwulan mendapatkan SK dinas untuk pertukaran tempat instansi dengan Kadmi. Pada saat Kadmi memimpin di korwil bidang pendidikan kecamatan Kedawung pertanggal November 2019 hingga saat ini dilakukan beberapa terobosan mulai dari visi misi korwil sebagaimana yang telah ditulis peneliti pada bab sebelumnya. Visi misi di sini berorientasi pada aspek pelayanan dimana terdapat signifikansi kebijakan dari transisi kepemimpinan sebelumnya. 
Dari cara memimpin yang diktator membuat pegawai merasa segan dan takut terhadap pimpinan, pegawai juga merasakan sungkan adanya gap antara pemimpin dan bawahan. Lingkungan organisasi instansi tidak kondusif, pegawai tidak dapat berbicara dengan leluasa baik dengan pimpinan maupun pegawai lainnya. Seperti contohnya ketika di instansi kehabisan air

satu indikator pada gaya kepemimpinan transformasional.

Poin selanjutnya yang mengindikasikan Kadmi menggunakan gaya kepemimpinan adalah pemberian motivasi. Ia berpendapat bahwa pemberian motivasi bisa dilakukan dengan lisan maupun tindakan. Dalam hal pemberian motivasi secara lisan ia sering berdiskusi ketika jam-jam istirahat atau pada waktu luang ketika ada permasalahan staf administrasi. Hal itu ia lakukan atas dasar kesadaran bahwa setiap pekerjaan pasti ada kesulitan yang mana dengan berdiskusi akan meringankan beban pikiran.

Dengan terobosan-terobosan yang dilakukan oleh Purwatisariwulan dan Kadmi membuat lingkungan kantor menjadi harmonis. Hal itu sebagaimana yang dirasakan oleh peneliti pada saat melakukan PLP selama dua bulan di korwil bidang pendidikan kecamatan Kedawung. Kondisi kekeluargaan kantor lebih terjaga dengan sering diadakannya makan-makan di internal kantor. Dengan harmonisasi internal ini membuat kinerja staf administrasi menjadi lebih optimal.

\begin{tabular}{lcr}
\multicolumn{2}{c}{ Berdasarkan hasil analisis tersebut } \\
dapat disimpulkan & bahwa & gaya \\
kepemimpinan memiliki & pengaruh pada \\
optimalisasi & kinerja & pegawai. \\
Kepemimpinan & otokratis & membuat staf
\end{tabular}

Kepemimpinan otokratis membuat staf
Aspek-aspek keteladanan, pemberian motivasi, peluangan waktu diskusi dengan para pegawai hususnya staf administrasi honorer, dan penerapan harmonisasi lingkungan kantor diutamakan. Dalam menjalankan roda kepemimpinan korwil bidang pendidikan Kedawung Kadmi secara pribadi menerapkan suri tauladan. Ia menganggap bahwa segala sesuatu berawal dari dirinya sendiri, ketika dirinya sudang baik maka lingkungan akan mengikuti. Hal ini merupakan karisma sebagaimana salah SIMPULAN DAN SARAN

Koordinator wilayah bidang pendidikan kecamatan Kedawung cenderung memakai gaya kepemimpinan transformatif. Hal ini dapat dilihat dari cara koordinator memimpin instansi korwil bidang pendidikan kecamatan Kedawung yang sudah memenuhi empat karakteristik dari kepemimpinan transformasional; karisma, motivasi inspiratif, stimulus intelektual, dan pertimbangan individual.

Berdasarkan hasil pembahasan dan analisis pada bab 4, penerapan kepemimpinan transformasional yang dilakukan Kadmi adalah dengan cara menata instansi menjadi lebih baik dengan menciptakan lingkungan organisasi yang kondusif dengan cara membenahi kantor agar lebih nyaman bagi karyawan, sering mengadakan syukuran makan-makan, menciptakan lingkungan organisasi yang menyenangkan yaitu dengan menghindari cara-cara repsesif dalam memimpin.

Berdasarkan pergantian struktur kepemimpinan di korwil bidang pendidikan kecamatan Kedawung selama 3 periode terahir, gaya kepemimpinan dapat mempengaruhi optimalisasi kinerja pegawai. Perbedaan kepemimpinan sejalan dengan perbedaan hasil kinerja bawahan. Kepemimpinan transformasional yang dijalankan Kadmi sudah berjalan baik, namun pada karakteristik indikator perhatian individual belum sepenuhnya 
administrasi hanya menjalankan tugasnya berdasarkan suruhan, suasana yang kaku membuat hasil menjadi kurang baik sebagaimana pengadministrasian yang belum rapih. Sementara kepemimpinan transformasional menghendaki adanya harmonisasi yang membuat hasil kinerja yang lebih optimal seperti pemberlakuan koding soft file kantor dan perbaikan pelayanan.

kecamatan Kedawung berdasarkan hasil penelitian ini antara lain: Sebagai masukan untuk korwil bidang pendidikan dalam mengimplementasikan gaya kepemimpinan. Pemilihan gaya kepemimpinan menjadi factor yang penting guna kemajuan instansi pendidikan.

Sebaiknya korwil melatih pegawai staf administrasi dalam melakukan pekerjaannya agar kinerjanya dapat lebih berkembang.

Alangkah baiknya korwil melakukan pendekatan di luar kantor guna mengetahui dan lebih membantu kebutuhan individu atau dengan kata lain lebih memperhatikan lagi aspek kesejahteraan pegawai honorer.

Kepada peneliti selanjutnya, hendaknya melakukan penelitian yang lebih mendalam lagi tidak hanya dari segi kepemimpinannya saja. Dan hendaknya menemukan aspekaspek lain untuk diteliti guna kemajuan instansi pendidikan.

\section{DAFTAR PUSTAKA}

Arikunto, S. (2016). Prosedur Penelitian: Suatu Pendekatan Praktik. Jakarta: Rineka Cipta.

Creswell, J. W. (2007). Qualitative Inquiry \& Research Design: Choosing Among Five Approaches. $2^{\text {nd }}$ edn. California: Sage.

Danim, S. (2004). Kepemimpinan Pendidikan: Kepemimpinan Jenius (IQ terpenuhi. Korwil tidak pernah melatih staf administrasi dalam pengadministrasian hard file maupun soft file. Tidak ada kedekatan di luar kantor sehingga korwil kurang dapat bisa mengidentifikasi kebutuhan individual pegawai atau dalam hal ini staf honorer karena kedekatan hanya terjadi di lingkungan kantor.

Saran-saran yang dapat diberikan kepada korwil bidang pendidikan

Meleong. (2011). Metodologi Penelitian Kualitatif Edisi Revisi. Bandung: PT Remaja Rosda Karya.

Miles, \& Huberman. (2014). Qualitative Data Analysis, A Methods Sourcebook Edition 3. USA: Sage Publication.

Rivai, V. (2013). Pemimpin dan Kepemimpinan dalam Organisasi. Depok: Rajawali Pers.

Robbins, \& Coulter. (2002). Manajemen (edisi 2). Jakarta: PT. Indeks Group Gramedia.

Siagian, S.P (2008). Kiat Meningkatkan Produktivitas Kerja. Jakarta: Rineka Cipta.

Sugiyono. (2013). Memahami Penelitian Kualitatif. Bandung: Alfabeta.

Sugiyono. (2010). Metode Penelitian Pendidikan Pendekatan Kuantitatif, Kualitatif, dan R\&D. Bandung: Alfabeta.

Sutopo. (2006). Metodologi Penelitian Kualitatif. Surakarta: UNS.

Thoha, M. (2007). Kepemimpinan dalam Manajemen. Jakarta: PT. Raja Grafindo Persada.

Wahjosumidjo. (2010). Motivasi Kepemimpinan dan Efektivitas Kelompok. Jakarta: Rajagrafindo Persada.

Yuki, G. (2010). Kepemimpinan Dalam Organisasi. Jakarta: PT. Macan.

https://AGORA-Vol.-5-No.-1-Tahun-2017Analisis-Gaya-Kepemimpinan-DirekturUtama-di-PT.-bukit-Mustika-Persada. Diakses pada tanggal Senin, 20 Juli 2020 
+ EQ), Etika, Perilaku, Motivasional, dan Mitos. Bandung: CV Alfabeta.

Djaelani, A. R. (2013). Teknik Pengumpulan Data dalam Penelitian Kualitatif. Semarang: FPTK IKIP Veteran.

Kartono, K. (2000). Penimpin dan Kepemimpinan. Jakarta: Rajawali.

Kurniawan, A. (2017). Metodologi Penelitian Pendidikan. Cirebon: Eduvision.

https://Jurnal-Manajemen-Tools-Vol.-11No.-2-Tahun-2019-dengan-judul-“AnalisisGaya-Kepemimpinan-Pada-PerusahaanKimia-Farma-(PERSERO)-TBK”. Diakses pada tanggal Senin, 20 Juli 2020 Pukul 14.18 WIB.

https//Jurnal-Media-Pustakawan-Vol.-25No.-4-Tahun-2018-dengan-judul-“AnalisisGaya-Kepemimpinan-MenggunakanTheory-Behavioral-Leadership-diPerpustakaan-ICBC- Yogyakarta". Diakses pada tanggal Senin, 20 Juli 2020 Pukul 14.24 WIB.

https//Jurnal-Administrasi-PendidikanPascasarjana-Universitas-Syiah-Kuala-Vol.3-No.-2-Tahun-2015-dengan-judul-“GayaKepemimpinan-Kepala-Sekolah-DalamMeningkatkan-Kinerja-Guru-Pada-SDNegeri-Lambaro-Angan". Diakses pada tanggal Senin, 20 Juli 2020 Pukul 14.53 WIB.

https://Jurnal-Ekonomi-Bisnis-danKewirausahaan-Vol.3-No.1-Hal.1-28Pengaruh-Kepemimpinan-Transaksionaldan-Kepemimpinan-TransformasionalTerhadap-Kepuasan-Kerja-dan-KinerjaDosen-Universitas-Tanjungpura-Pontianak. Diakses pada tanggal Sabtu, 11 Januari 2020 Pukul 02.28 WIB.

https://Jurnal-Moderat-Vol.5-No.1-GayaKepemimpinan-Kinerja-Aparatur-Sipil-Negaradan-Partisipasi-Masyarakat-Terhadap-
Pukul 13.45 WIB.

https://Jurnal-Perpustakaan-Vol.-9-No.-1Tahun-2018-dengan-judul-“AnanalisisGaya-Kepemimpinan-Kepala-

Perpustakaan-(Studi-Kasus-PerpustakaanGrahatama-Pustaka Yogyakarta)". Diakses pada tanggal Senin, 20 Juli 2020 Pukul 13.57 WIB.

https://Prima-Ekonomika-Vol.9-No.1Pengaruh-Gaya-Kepemimpinan-danKomitmen-Organisasi-Terhadap-DisiplinKerja-dengan-Kepuasan-Kerja-sebagaiVariabel-Intervening. Diakses pada tanggal Sabtu, 14 Desember 2019 Pukul 10.20 WIB.

https://Isrorina-\&-Widhy-Setyawati-Vol.6Hal.19-31-Pengaruh-PemberdayaanPegawai-dan-Karakteristik-PekerjaanTerhadap-Kinerja-Pegawai-denganMediasi-Iklim-Organisasi-pada-SekretariatDaerah-Kaabupaten-Pekalongan. Diakses pada tanggal Sabtu, 11 Januari 2020 Pukul 03.29 WIB.

https://Galang-Surya-Gumilang-Vol.2No.2-Hlm.144_159-Metode-PenelitianKualitatif-dalam-Bidang-Bimbingan-danKonseling. Diakses pada tanggal Jumat, 14 Februari 2020 Pukul 00.34 WIB.

https://Melin-Rosintan-\&-Roy-SetiawanVol.2-No.2-Analisis-Gaya-KepemimpinanPerempuan-di-PT.Ruci-Gas-Surabaya. Diakses pada tanggal Selasa, 18 agustus 2020 Pukul 11.15 WIB. 
Pembangunan-di-Kecamatan-Kulo-Kabupaten-

Sidenreng-Rappang. Diakses pada tanggal

Selasa, 17 Desember 2019 Pukul 23.17

WIB. 